\title{
FUN AND GAMES AS A FORM OF PHYSICAL CULTURE IN THE TRADITIONAL RELIGIOUS AND SOCIAL RITUALS OF THE LEMKOS. THE ETHNOMETHODOLOGICAL APPROACH
}

\author{
ERNEST SZUM, RYSZARD CIEŚLIŃSKI \\ The Josef Pilsudski University of Physical Education in Warsaw, \\ Faculty of Physical Education and Sport in Biała Podlaska, Department of Pedagogics \\ Mailing address: Ryszard Cieśliński, Faculty of Physical Education and Sport in Biała Podlaska, \\ Department of Pedagogics, 2 Akademicka Street, 21-500 Biała Podlaska, \\ tel.: + 4883 3428776, fax: +48 83 3428800, e-mail: knh@awf-bp.edu.pl
}

\begin{abstract}
This article presents the Lemkos games and fun as popular forms of physical culture of the Lemko community living in former areas of south-eastern Poland. It presents them as part of the intangible culture of the vanishing ethnic group. The traditional elements of physical culture of the Lemko community, especially fun and games have been presented on the basis of the general characteristics of this ethnic group, and the entire history of the presence of the Lemkos in Poland. Folk fun and games, as a form of physical activity are presented in the broad sense of physical and cultural system and the Lemko community located within the cultural system. The need for such a study is due to the fact that there are no other ethnological or cultural anthropology studies on physical culture of this ethnic group.
\end{abstract}

Key words: Lemkos, physical culture, fun and games, religious rites, social rituals, leisure sociology, ethnology, cultural anthropology

\section{Introduction}

In European culture, traditional games and activities of folk nature, as well as dances and other forms of physical activity are an important component of any national culture [1]. Games and fun, despite the variety of forms depending on the historical periods and areas, their social and cultural legitimacy, are cultural universals that give meaning to the of individual and collective experience of the man [2]. Traditionally various forms of physical activity, including games, are created and formed spontaneously in communities functioning according to the rhythm of the seasons and which is determined by the ritual calendar [3, 4].

The purpose of this paper is to present various forms of physical activity performed in the Lemko community, living in the former areas of the south eastern Poland. This issue is all the more important that the changes in Central and Eastern Europe at the turn of the century increased the importance of small local communities and national minorities.

One of the main problems that should be raised is the question - whether or not modern Lemkos retain and use traditional forms of their own culture and values, including physical education. An important issue is also to indicate traditional cultural values, a system of patterns and behaviours that have been developed over several decades, and distinguish the wider culture and physical culture of the local communities from other communities - ones that had succumbed to unification processes taking place in contemporary Europe.

Minorities living in the eastern part of Poland have over the centuries developed their own specific patterns of behaviour, effort and attention to health and hygiene, nutrition and value for leisure and recreation. These experiences did not appear in the consciousness of those minorities as signs of physical culture, but were daily basis and festive activities.
During the 2011 National Census the Lemko nationality was declared by 10,000 people, compared with the 38.5 million population of Poland, including half of the respondents surveyed declaring it as the only nationality, 2,000 people indicated it as their first nationality, with other nationalities also declared, and 3000 people declared it as a second nationality [5]. Therefore, it is still one of the most numerous ethnic minorities in Poland, despite the emigration wave and dispersion of the members of this community, which took place after the Second World War. The Lemko population now live in the southern belt of the following voivodeship: Podkarpackie and Małopolskie, the eastern belt of the lubelskie voivodeship, eastern part of Mazowieckie voivodeship (poviat Łosicki) and the southern part of Podlaskie voivodeship (western boundary line outlines: Bielsk Podlaski - Siemiatycze - Parczew; Łęczna - Krasnystaw - Zamosc - Biłgoraj - Leżajsk - Jaroslaw - Krosno - Gorlice - Szczawnica) [6]. The modern Lemkos are heirs of a rich and original culture, including physical culture, which is an important element of fun and games.

Physical culture perceived in the ethnomethodological perspective of the Lemkos as a diverse entirety and at the same time a part of the broader culture, developed on the basis of tradition and contemporary experience of this ethnic group. It is perceived and felt by members of the Lemko in a number of ways: it has a distinct meaning and functions in relation to the roots from which it comes, is specifically internalised and lived by individuals belonging to this ethnic group and contributes to the construction of its identity and autonomy. However, crosscultural comparative studies, analysing the patterns of physical culture suggest that ethnically determined somatic core values are universal $[7,8]$.

In addition to historical sources and monuments of tangible culture that can be used to recreate the past of the Lemkos, including the history of their physical culture, another group of 
equally valuable source are ethnographic materials. By this we mean, first and foremost, various tales and legends, which are the only and the last testimonies of intangible culture specific areas, including physical culture, are sometimes invaluable historical sources. They communicate knowledge of Lemko community about their own past, festivals, social customs, work and leisure time games [9]. While still in the period between two world wars verbal reports of the Lemkos could be a relatively rich source of knowledge about the past of this ethnic group now this kind of research material is practically unavailable. The historical knowledge as legacy of the Lemkos, passed on to future generations in the form of verbal tradition, passed away in oblivion along with the people whose lives have gone. This knowledge had not well established in the minds of the more and more dispersed and almost completely been assimilated Lemkos minority in the Polish society. The contemporary ethnographic research conducted on Lemko culture allows to record only fragmentary information, which also carries a high degree of fault errors and uncertainty, especially as far as details are concerned. Therefore, the field research conducted in 2011 for the purpose of this study, in the areas inhabited by the Lemko community, did not bring the expected results in the form of a rich source of material. Therefore, the description and the structural and functional analysis of the issues and the findings presented in this paper, due to this necessity had to be based mainly on historical records.

\section{Materials and testing methods}

The relationship of culture to the whole of social life of the studied group is the paradigm of contemporary cultural anthropology, and the main task is to demonstrate the ethnological study of its cultural specificity [1, 10]. Due to the fact that as a result of field research conducted we were unable to obtain sufficient source material, the second part of the study was carried out during the Lemko community annual event presenting the Lemko culture - the XXIX Lemko Watra, held on 22-24 July 2011 in Zdynia (Żdynia). The selection of respondents was random, and the respondents were represents of the Lemko people from different clusters of this ethnic group in Poland. We used the qualitative survey method and the technique of free interview and observation [11]. The description and the structural-functional analysis of the research topics were supplemented by historical records. The main aim of the study was to demonstrate the presence or absence of links between the general culture of the Lemko population and the physical culture specific to this ethnic group.

\section{Outline of the Lemko history}

The Lemkos, belonging to the group Eastern Slavs, used to be referred as Rusyns or Rusnaks [12]. In Poland, for centuries they inhabited the northern slopes of the Carpathian Mountains. As far as their origins are concerns, even among the Lemkos themselves, there are different views. Polish researchers present the theory of the origin of this group, as wandering Wolochian or Wolochian-Ruthenian peoples, which is evidenced by archaeological research; proponents of the proUkrainian option argue that the ancestors were Ruthenians inhabiting of ancient Kievan Rus', while representatives of the Lemko people derive from the White Croats who lived in the Carpathian region already in the fifth century [13]. In the seventh century, the majority of this tribe's population moved to the Balkans, and the other were conquered by the Kievan Rus in the tenth. It is assumed that the name "Lemko" (Lemko, rarely Lemkin) was established in the first half of the nineteenth century, on the Lemko-Boyko borderlands. Initially it was a nickname used for the Ruthenians, who in their speech used the term „łem”. Over time, it has lost the character of nickname and become a neutral name used in the literature and scientific terminology. The Lemkos, who called themselves "Rusyn" or "Rusnak", gradually took over the name, but until the First World War it was hardly ever used. In the interwar period it was used by Lemko activists, and after World War II, the name "Lemko" became dominant and almost completely replaced the old name "Rusnak" [14, 15, 16].

The Lemko people for centuries had been followers of Eastern Christianity, and many representatives of this ethnic group pride themselves in having been baptised in the ninth century by the Saints Cyril and Methodius. Currently, the Lemko population is divided into Orthodox and Greek Catholics. The most enduring legacy of their national identity include: the Eastern rite, the Julian calendar, Orthodox churches, liturgical books written in the Cyrillic alphabet and religious songs [15].

The territory recognised by the Lemkos as their homeland, called by them Lemkovyna, ranging from Pieniny Mountains in the west to the mouth of the Osława River to the San River in the east. The Lemkos lived in the Low Beskid and parts of Beskid Sadecki and a small piece of the West Carpathians. The northern border of the Lemkivshchyna was defined in the interwar years, as the boundary between the Polish and Ruthenian population. The main area of the Lemko region was relatively ethnically homogeneous. Poles were a small minority here, a large part of the population were purely Lemko villages, with very few Polish settlements [17]. Before World War II in Poland the Lemko population in Poland was quite dense. They lived in more than three hundred villages [18].

During the Second World War, Lemkos initially voluntary began to move to the Soviet Ukraine and deep into the Soviet Union. Over time, these displacements were getting more intense, and under the influence of the Ukrainian nationalist propaganda they had become compulsory, which was sanctioned by the agreement between Poland and the Soviet Union on exchange of population [19, 20].

After the Second World War, in the spirit of transformation of Poland from multinational state into a homonational state, the communist authorities decided to liquidate the Lemko minority, making the first step - in 1945-1946 - the majority of the displaced communities in Ukraine, and in the spring of 1947 years violently deporting the remaining Lemko in the number of about 40,000 in the so-called Recovered Territories $[21,22]$. Assuming that before the Second World War in the Low Beskid there were about one hundred thousand Lemkos, and after the "Wisła" operation, these areas had become almost deserted [23]. The intention of the authorities was to disperse them, in order to avoid the settlement in a large integrated group. During the operation conducted under the codename of "Wisła", resistant Lemkos were imprisoned in a camp in Jaworzno. As a result of accusation of the Lemko-Rusyn communities of encouraging the rebellion caused by the Ukrainian Insurgent Army (UPA) in 1947, the "Wisła" operation led to displacement of almost the entire Lemko population. As a result, Lemko families remaining in Poland or located in Ukraine and Russia, usually underwent denationalization - Polonisation or Ukrainianisation. However, despite many difficulties, the older generation tried to maintain the Lemko culture. It was easier in Poland following subsequent "thaws" [24]. In 1956, there was a short lived opportunity for Lemkos to return to their homeland. Then, about 5-10 thousand people returned to Lemkivshchyna. However, most of Lemko villages, they would have wanted to return to, no longer existed at the time. For this reason, many Lemkos remained in the western provinces. Many also lived in large cities: Wroclaw, Krakow and Warsaw. Still others settled permanently abroad, including a large group, 
which settled in the United States [25, 26].

Lemkos used to engage in many now disappearing professions: gonciarstwo (traditional roofing technique), maziarstwo (manufacture of wood gunk used for the lubrication of wagon axles), cooperage (manufacture of the wooden dishes using the stave technique) spoon making (manufacture of wooden household items), or dziegciarstwo (dry product of wood distillation, antibacterial used in folk medicine). Men often engaged in glaziery, and Lemko women specialised in weaving. There were also a number of stonework centres in Lemkivshchyna, where millstones, grindstones and various hones and whetstones were made from locally mined sandstone [18, 20].

\section{Ethnological and ethnographic context of Lemko fun and games. Game elements in religious ceremonies and social rituals}

The cycle of rituals in the social life of Lemkos did not begin at the beginning of the calendar year, but in the night of $29^{\text {th }}$ to $30^{\text {th }}$ November, with the rite of St. Andrew, now better known as the popular St. Andrew day [27]. All field work had already been completed, and the entire community concentrated their interest and participation in rituals that were intended to ensure success in next coming year.

The first St. Andrew's day omen, which was attended by all members of the extended Lemko families was Trześniowe. At the cottage orchard they would break as many cherry twigs as there were household members. Then the twigs were placed them in a bowl of water, and each of them assigned to a particular person. If anyone's twig bloomed any the time of Christmas Eve, this would indicate good luck, and if not, it meant certain death [28]. However, in the case of maidens, the good luck would indicate imminent marriage.

On the night of St. Andrew unmarried girls would try to make predictions on the possibility of marriage. On the bench next to each, they would place pairs of flax bundle, which they would name, giving them their own names and those of their chosen ones. Then would set fire to them and watched the ashes. These couples, whose ashes merged, were expected to get married soon. On starry nights, girls would come out of the huts and counted pales in the nearby fences. In this way they tried to predict whether their husbands will be youngsters or old men, bachelors or widowers. The answer was indicated by the end of the counting at the last pale. In addition, maids would throw treats in the form of pieces of cake to local dogs. The cake pieces would indicate bachelors. The girl whose cake was eaten first by a dog, this was the first one to get married. A peculiar way of matrimonial divination was visiting a pigsty. An impatient girl would knock on the pigsty door asking, "Puk, puk swynia, budu ja toho roku gazdynia?" (Knock, knock swine, shall I be a married woman this year). Pig grunt would signify a confirmation, and lack thereof would herald continuation maidenhood [29].

Another popular form of fortune telling, also commonly known in other ethnic groups and other parts of the country, involved pouring wax and trying to interpret the shape of the pieces created after the freeze, or cast their shadows [30]. Initially these rites were treated very seriously, and the divination was celebrated alone, in isolation and secrecy. Later, they took the form of collective play in peer groups to eventually turned into a casual parlour game involving the both genders (men previously had their counterpart in the form of St. Catherine's day) [31].

A day devoted to specific type of divination was also 13 December each year. It was always a day of increased mobility. People would pay attention to who first entered the room. If this person was a man from the upper part of the village, it heralded bad luck, usually associated with a natural disaster like a flood, fire, or damage to crops such as hail. If the first person to enter the room was a man from the lower part of the village, it heralded peace, harmony and universal happiness. If the first person to come in was a woman, no matter what part of the village she came from, it was a bad omen. To undo the evil spell was, such a person would be given peas and oats, which then they had to eat [32]. The genesis of this specific divination tradition on this day is unknown.

Before Christmas there were held Weczyrky (Evenings), i.e. meeting in various homes in the village, accompanied by all kinds of fun, singing songs and visits in disguise. In the period around Christmas in Lemko villages carol singing took place. It however, did not contain elements fully typical of the Christian tradition, although there were some similarities [33]. Carollers often wore fur coats turned inside, their faces were covered with various kinds of traditional masks, wielded especially prepared traditional fun accessories such as plaited straw whips. Carollers included King Herod, and with him a soldier, an angel, a Jew, three wise men, a wizard with rotating star, a goat with a movable lower jaw and bells hanging on the horns, death and devil. The latter one, jumping and kicking in the snow, performing acrobatic figures would run up to the door, knock three times and then asked, "Cy pozwolyte koladuwaty, wasz dim rozweselyty, Iroda zasmutyty?" When he heard Mary saying: "Prosimo koljadujte", with the other carollers he would sing in front of the house: "Syn Bożyj narodywsja, oj raduje sja zemla". Once in the chamber, they improvised a fragment of the biblical tale of the evil Herod, who upon hearing of the birth of Christ commanded to murder all the babies for which he was deservedly punished. After the carols, they sang humorous songs, dancing simple dances to them. Then the voices of carollers sang: " Oj husi, husi, husi na staw. Dobryj deń Maryś iszczym ne spaw. Iszcze jem ne spaw, spaty ne budu. Hodyna do dnia, tancowaty budu" [33].

Christmas Eve in the Lemko tradition of was generally regarded as a holiday. Every family in Lemkivshchyna celebrated that day with great solemnity, though customs in various villages were slightly different. Sometimes even that within one village, Christmas Eve would be celebrated differently, if the village was large. On Christmas Eve, children were disciplined and could not indulge their natural tendencies involving skirmishing and games. They had to be extremely polite, not to disturb the adults in the preparation of the holidays. All household members worked fairly and efficiently, so that - according to the superstition - their work would be just as efficient in the coming year. In all houses older children, mostly girls, decorated Christmas trees, which Lemkos used to call Jaliczki - i.e. called firs. The custom of the Christmas tree decoration arrived to Lemkivshchyna at the turn of the century through the returnees from the United States [34]. Initially, Christmas trees were decorated in rich home or homes where there were small. Christmas trees were places on wooden trestles and were placed directly on the ground in front of a window or on the bench, or even on the table. They were decorated with chains of white paper and cut straws, clowns made from empty egg shells and paper baskets. In addition, Christmas trees were decorated with apples, nuts and homemade cakes. At the top of a Christmas tree there was always a star. How long charismas trees were kept would vary, however it was usually until the New Year or Epiphany. Decorating Christmas trees was the task of children and youths, as the adults were tired of physical activity associated with other preparations for the holiday [35].

Women engaged in preparing supper. They would devote special attention to baking bread, preparing dough with flour containing all kinds of cereals. Inside each loaf there was a bulb of garlic. When the bread was being baked, superstitious woman would jump up and down - to make sure the baking was suc- 
cessful. They used to bake three special oblong loaves. The first one, was for cattle, and was also baked with garlic. The second one was wrapped in linen yarns, and was for "połaznyk" i.e. the first guest (but only male), who appeared in the house that day. The third one was baked "just in case" to make sure that the family does not run out of bread in the event of any unforeseen circumstances, such as visitors, although there was no habit of Christmas visits, and all things had to be put aside for the time after Christmas. Then the oldest woman would sweep the floor in the chamber. The children asked her, " Szczo tut zamiatajetie?" The woman would reply: " Szob na nastupnyj rik toho nie buło, a wsije złe, błahi, blisznici, kukiel i sniten z pszenyci uszli" [6].

After the sunset, all members of Lemko families would go down to the river to wash in running water. If the river was frozen they would make an air hole. The oldest man would stand above the air hole, he would take water in his hands and wash his face three times. The remaining members of the family would then follow his lead. In some villages, such as Muszynka, Izby, and Tylicz the oldest people would do the washing ritual in the house, when one of the younger members of the family brought water in a wooden bucket with small pebbles from the river. There was also a custom of throwing small change into the water, e.g. in Muszynka, Szczawnik and Wawrzce, which was supposed to herald good health and prosperity, and make the man as vigorous as water and unbreakable as steel. If someone was ill, this ritual was intended to bring them back to health. At the end of the ritual, the bucket of water was placed next to the table, and during the Christmas Eve supper they would throw three spoonfuls of each dish into the bucked, which was then fed to animals. On Christmas Eve the farmer also shared bread and garlic with the cattle, which was to ensure good health of the animals [35].

On the Christmas table they also would put hay, grain and flax. A prepared table would be covered with a white cloth, on which they would lay the bread and had a pot of wheat or barley with a candle placed in it. After putting out the candle they would engage in fortune telling from the smoke. If the smoke went up, it heralded a wedding, if it went towards the oven it heralded baptism, and if went towards the door, it heralded death [27]. They would place wooden spoons around the table. The number of unoccupied seats left at the table was equal to the number of family members who had passed away. The supper would begin, when the first "star" appeared on the sky. Wafer was unknown amongst the Lemko people, instead they would share wheat rolls. They would eat garlic bread and drink a shot of vodka. There were twelve dishes, and they ate them one by one from the bowl. The first were the mushrooms with bread, then oatmeal soup with potatoes, dumplings with cabbage, cooked cabbage, peas, large beans, beans, pearl barley with dried pears, dumplings with honey and poppy seeds, dried fruit compote of pears, small yeast rolls, borsch with potatoes or dumplings with mushrooms. At the end of the supper, they would clean the table, as it was believed that on the night, souls of the dead would have their feast [35].

The Christmas day was celebrated by the Lemko people with great solemnity. It was a day of peace and universal respect. After the Christmas Mass in the church, which was long and tiring physically, the whole day was spent resting with other family members. On that day, they would not prepare any meals or clean the table. They'd simply eat the dishes left over from the Christmas Eve supper. On that day no one was allowed to go to sleep as it was superstitiously believed that water could flood the hay or potatoes would be overgrown with weeds [35].

The Boxing Day was the Cathedral of the Holiest Mother of God. On that day, people could visit one another. This was accompanied by characteristic games involving fortune telling. In the morning they would sweep the chamber, and when garbage was being thrown out, a maid would scream to make echo and find out, where would her fiancé come from. A maid would bring a bunch of wood. The number of wood pieces would indicate whether or not she would be getting married soon - i.e. an even number of pieces indicated that she would get married that year, and an odd number of pieces indicated hat it would happen sometime in the future [35].

On the third day of Christmas they celebrated St. Stephen's day. They celebrated vespers, which emphasized his martyrdom. On that day they would bless oats and spray its grains on one another. There also dances, music and other plays. They would hold the so-called Łamanec crowning the cycle of Weczyrki. Preparations for the fun and games would start early in the morning. At the place, where the pays were to be held there was a growing crowd, which was just waiting for the signal to start dancing. Fun began in earnest after the musicians gave the signal. Dancing couples would switch partners, dancing to and from bumping, poking, stepping on each other's shoes from bovine skin and rigid boots, waving embroidered scarves and whistling to the tune of music. On the benches around the vast chamber there would be lying in disarray various sheepskins, coats, hats with rolled up brims and sheepskin hats covered with blue cloth. Spirited couples danced the cross dance [35].

Based on our research findings it appears thirteen days after Christmas, celebrated among Catholics of the Roman Rite (which results from taking the old style calendar by Lemkos) the feast of Rizdwo was celebrated, also referred to as Rożdżestwo Izusa Chrysta (Birth of the Jesus Christ). As in the Roman Catholic Tradition the Rizdwo period was preceded by Advent, during which rizdwiany pist - i.e. severe fact was obligatory. Despite this, the period of waiting for the birth of the Saviour was not perceived by the Lemkos as a time of sorrow or reflection. During this period they often used to meet in homes during wieczirki, when women would gather to clean houses and prepare the home for the holiday. Such gatherings were also attended by boys, who dressed up as various characters - for instance Gypsies, Jews, Christmas mummers, heroes on hobbyhorses or the very popular in the Lemko folklore four "baczów". They would perform humorous skits and sing shepherd songs. Very often they would organise social games, mainly intended to pair up boys with maids. The most popular of the games and activities included: Peczenie Kohuta (Roasting the Rooster), Mosty (Bridges), Ślepy Wójt (Blind Village Leader), Gąski i Wilk (Goslings and a Woolf), Dupak (Backside Beating).

Data collected during the study indicate that a popular holiday in the Lemko community, which has survived until this day is Baptism - i.e. the eve of the Jordan holiday. On that day at six in the morning, the whole family would go to church. Then, with lighted candles and banners a procession would go down to the river. The priest would bless water, and from that moment it became Jordanian water. During washable Jordanian woman took her hands and rubbed a dime faces them. Wash in running water was to ensure their health for the next year and financial wealth.

When washing with the Jordanian water women would take 10 grosz coins in their hand and rubbed their faces. The washing in river water was intended to ensure good health and financial prosperity for the coming year.

The information we have gathered suggests that from Rizdwo to Jordan people used to engage in never ending fun and games. Holiday carollers visited homes with a goat and a Christmas mummer; there were also the three wise men with a star. There was also a Gypsy demonstrating a parody of the "Gypsy prayer", Jew selling hearings and smearing girls' faces with soot, and even "miśkarz" demonstrating bull castration techniques. There were monsters dressed in white and ghosts girded with rye straw strings. In fact, they were mostly young boys with sticks with bells and conical straw hats with ribbons falling on 
their chests. They'd run around the room trying to catch frightened girl's, in order to steal a kiss. There was also Death dressed in a white robe with a scythe in its hand, which pranced between the tables, but it was quickly pushed outside. The same was with the devil, which was usually accompanied by a bear.

The interviews conducted during the course of our research indicate that on the first day of Easter, after the Mass in an orthodox church young people used to engage in fun and games in front of the church. On this day, Lemkos used to go down to the river to see fish. Anyone who succeeded would be as fit as a fiddle and could expect good luck. The boys ran from house to house and collected painted Easter eggs from the maids. On Monday, again they would visit the maids, but instead of collecting eggs, they would engage in "Wodolanie" (Water Splashing). They poured buckets of water on one another, caught girls were dragged to the creek, and mercilessly dipped the water. A girl going to church could sometimes bribe the boys using Easter eggs, but this was not always effective, and sometimes she would be soaked anyway. Streams of water would wet them to the skin. But the girls would always try to get even. Sometimes they would grab watering cans and pour water directly behind the boys' linen shirt collars.

Pentecost in the Eastern Church, referred to by the Lemkos as Rusalia, was celebrated as a spring festival. Roofs were decorated with hazel. A procession around the fields with a priest and banners was held. It was also the feast of shepherds. They burned fires, decorated cattle with lime, ate scrambled eggs and drank alcohol. In the evening, young people burned fires [36]. Boys and girls were showing off, jumping over the fire. If a girl failed to get a good jump and fell into the fire, she was considered a witch. That day was an opportunity to establish relations between the inhabitants of villages scattered among the hills [37].

St. John's day, also referred to as Sobótka or Kupała, was celebrated similarly as the feast of Rusal. Responsibility for the preparation of Sobótka rested on the shoulders of the shepherds. A few weeks earlier, they cut down juniper and firs, forming a stack several metres high. The stack was located on a hill visible from every place of the village. On each side they would add an armful of fresh sprigs of spruce, at the end sprinkling all with needles. Clouds of white smoke attracted almost all the inhabitants of the village, who, before leaving their houses extinguished the fires in the furnace to be able to reignite it late at night with torches lighted in the Sobótka fire. Women throwing blessed herbs on the fire sang: "Jane, Jane, swiatyj Jane, oświat że nam nasze zila, drobny pisok i kaminia”. Meanwhile, the boys ran around the fields with burning torches. They circulated among the people, carrying bundles of joyful light. Burnt firebrands were thrown on potato or cabbage fields and other crops. This was to ensure a better harvest and protect the corps against pests. When the fire was out, they would rake up the smouldering ashes, making an embankment and jump over it. The skin of their feet was hardened from the constant walking barefoot, so that they were able to easily walk on hot carbides. Everyone sang and danced, while the Sobótka fire was burning. The best-known social game taking place on the night was one named exactly the same as the celebrated day - i.e. Sobotka. It began the night before the Feast of St. John, and continued until dawn the next day. The game was played mostly by young people. Girls and boys lined up alternately in the form of a circle, tangled their arms and danced around the fire. Then a boy would choose a girl, and they would dance together. All this was accompanied by chants and folk music, mostly oberkas. Listening to a band playing country and choral singing they danced around the fire, moving in the clockwise direction. Topics addressed in the songs related to everyday life and the problems of the villagers [38]. The celebration of Sobótka was the closing of the spring ceremonies cycle [39].

\section{Exemplifications of Lemko fun and games}

The information gathered during our research activities indicates that the most popular Lemko games included: Kiczka (Stick), Peczenie Kohuta (Roasting the Rooster), Ślepy Wójt (Blind Village Leader), Mosty (Bridges), Gąski i Wilk (Goslings and a Woolf), Miotlarz (Sweeper), Dupak (Backside Beating). They are still incidentally practiced in these days, but mostly during folk events and games organised by representatives of the Lemko community for children and young people belonging to this ethnic group. Only the Mosty (Bridges) game has already been completely forgotten. Not only the game itself has been forgotten, but also the very essence of it is no longer possible to determine.

Kiczka is a team game described by our respondents, suitable for a small number of participants. The game is started by a person selected in a lottery, who stands next to a hole dug in the ground with a Kiczka - i.e. a short stick put over the hole. This spot, where the game is started is usually called "the winning spot", but also "home" or "kingdom". The other people participating in the game, stand in straight line at designated spots, 10, 15, 20 .. etc. steps away from the hole (depending on the number of participants). These places are called "the losing spots". A player standing in the "winning spot" places a "knocker" - i.e. a long stick under the Kiczka, and with a dynamic movement knocks the Kiczka forward as far as possible in the direction of the people standing on the "losing spots". Their task is to catch the flying Kiczka. The one who grabs the flying Kiczka takes the spot of the knocking player, who in turn stands on the losing spot. If no one succeeds in grabbing the flying Kiczka, the knocking player puts the "knocker" across the hole. Now, one of the players (usually the one closest to the Kiczka) has to throw the Kiczka and hit the knocker placed across the hole. If he is successful, then the throwing player switches places with the paying player, and if he misses, he starts the game again. This time, he sticks the Kiczka vertically into the hole. The knocking player attempts to hit it with the "knocker", so that it rises upwards, and once it's in the air, he tries to knock it as far away from the hole as possible. If a player standing on one of the "losing spots" catches the flying Kiczka, he sores a so called "kampa" and moved to the "winning spot". If the knocking player fails to knock the stick in three attempts, he leaves allowing the next player to make an attempt. The game ends, when one of the players reaches the place most distant from the "kingdom" and comes back.

The research has demonstrated that the most popular social game amongst the Lemko youth, involving elements of physical activity is Peczenie Kohuta - i.e. Roasting a Rooster. During the game a boy sitting on the table, holds a wooden sceptre in his hand with a charred cloth wrapped around it, he calls upon one of the girls gathered in the rooms, and she has a choice, either to kiss him, or if she refuses, she will have her face smeared with the charred cloth. The boy usually looks at her with misty eyes, expecting a quick decision. If a girl refuses to kiss him, she is adequately punished, and the boy points the sceptre at another girl. The next one immediately sticks her lips to his cheek, while the other participants of the game are calling: "Pecze sia kohut pecze, aż z nioho smalec tecze. Naj sy panna toho wybere, koho sama chocze". The game goes on, more girls are called, and the game ends when there are no more girls to call.

Ślepy Wójt (Blind Village Leader) is a social game described by our respondents, in which one of the players is selected to be the Village. Other play roles of his wife, son, daughter, niece, nephew etc., depending on how many player's there are. The Village Leader runs around the group of people calling: "The village leader is arriving, and he's bringing...", and now he names a person who joins him. Then the same set of activities is repeated, and the person who joined the leader sings and calls 
together with him. The game is continued until all participants have joined the leader, and then the game is concluded. A similar game is played in the region of Mazovia, where it's called Pan Starosta (Governor).

Another Lemko game described by our respondents - Gąski i Wilk (Goslings and a Woolf) is very similar. Goslings and wolf are characters played by participants of the game. The oldest or strongest of them become: mother of the goslings and another one becomes a wolf. The mother of the goslings is to protect her children. At the beginning of the game the goslings line up behind their mother and hold their waists. Then the wolf sits in the middle of the playground (or the place, where the game is being played) and lights a small fire (or pretends to do so, if the game is being played indoors). The wolf's task is to catch all the goslings, starting with the last one on the line, right to the mother, at which point the game ends. At the next stage of the game the goose mother and her goslings walks slowly around the wolf several times and asks him: "What do you need this fire for?" And the wolf says, "To boil the water ...". The goose mother asks further: "And what's the water for?" The wolf again says, "to wash the plates ..." The mother goose stubbornly continues: "and what are the plates for?". The wolf equally patiently replies: "To eat goslings...". In an uncertain voice the goose mother asks again: "and where are they?". "They are all behind you!" - responds the wolf and tries to grab the last gosling in line. The cycle is repeated until the wolf has caught the last gosling or gives up at a stage. In other parts of Poland this game is also well known, although in slightly different ways and with different dialogue. In some regions play ends with a scene where the captured goslings pretend that the wolf had crippled them - i.e. they jump on one leg. The goose mother cries at the wolf, "Why did you hurt my goslings?". And the wolf says: "Why did you eat my oats and millet, and drank the whole pond of water?" The goose mother say: I'll pay the damage, but you wolf, fix my goslings up. Then, the wolf strikes the goslings' feet with a bullwhip, so that they no longer limp.

Another game described by our Lemko respondents and based on a similar pattern is Miotlarz (Sweeper). This is a game that is usually played indoors. The game's scenario is as follows: one of the players walks around with a broom inside a circle made by dancing couples, and pretends to sweep the floor. The other players dance around in couples. From time to time the sweeper touches one of the couples with the broom, as if trying to guide it towards the right track, but in fact changing their direction of dance. All of a sudden, he spectacularly hits the broom against the floor several times. As soon as this happens all players try to change their dance partners, and the Sweeper, taking advantage of the chaos tries to find a partner for himself. The dancer, who fails to find a partner, takes over from the Sweeper.

The information gathered by us indicates that a popular social game for several or even a dozen or so participants, amongst Lemkos is Dupak (Backside Beating). This game can be played outdoors as well as indoors. The game is quite simple: one of the players - Dupak, who is blindfolded, sticks out his backside. One of the other players hits his backside with a hand or an object - e.g. a belt or a boot. The Dupak's task is to guess who hit him. If he succeeds, then he switches places with the hitting person. If not, then he stays, where he is and he is hit again, and the game begins over. In other regions of Poland the game is played in a similar form, and is known as Salonowiec.

Jewish fun and games used to be quite popular in the Lemko community, however their presentation goes beyond the scope of this study [9].

\section{Summary and conclusions}

Analysis of the material gathered during the course of our research has demonstrated that fun and games associated with the religious ceremony and social rituals are of paramount importance for the strengthening of the social ties existing within ethnic groups and developing new ones. Games performed in public, being a manifestation of social life, facilitate it for the Lemkos acknowledge the distinctness of their ethnic group, and foster their sense of community, while the element of competition present in the games triggers reflexes of solidarity. On the other hand, the collective activity taking place during such games additionally strengthens the social ties and triggers the cooperation and coordination of activities performed jointly. The joint physical activity, being an integrating factor, initiates and enhances interpersonal interactions, favouring the development of interpersonal relationships, as well as brings together Lemkos from various parts of the country and even the world. The traditional elements of physical culture of the Lemko people are a very important part of the shaping and strengthening of their national character.

As a result of the research we have determined that there are patterns of physical culture and physical activity specific to the Lemko community. Physical culture of the Lemko community is characterised by physical activity containing elements and features not found in the culture of other nationalities and ethnic groups. This refers to everyday life activities demanding physical activity - work and leisure, as well as religious rituals and festive social rituals. This applies in particular all kinds of games and activities practiced by adults, adolescents and children, on weekdays and during various holidays.

Attitudes and behaviour patterns in the area of physical activity - and more broadly physical culture, are a part of the ethnic culture of the Lemkos living in Poland. A culture, which is not destined to disappear completely, but after a period of crisis, has entered a phase of progression, thanks to the global trends to seek one's roots and take pride in one's origins. Strangely enough, this is largely a result of the ongoing globalisation process and the formation of post-modern societies, and the multi-ethnicity multiculturalism associated with these phenomena as well as practiced and promoted in contemporary Europe, which in turn is to some extent a consequence of the extension of the EU.

The socio-politico-economic changes and the consequential democratisation processes, carrying freedom in economic life and tolerance in social relations, favour disclosure of the specific manifestations of the Lemko national culture, including physical culture, and bring about a revival of traditional forms and patterns of life of national minorities and ethnic minorities in the sphere of physical culture. Unfortunately, the state's education policy makes little provision for cultural minorities, disclosed in the course of social change (in practice only local governments take this into account), which creates a barrier to popularisation of the traditional forms of physical culture that are specific to those minorities. At the level of local activities, ethnic distinctness is promoted by the ethnic minorities themselves in the form of grassroots activities and associations established by them. As a result of the lack of sufficient support of ethnic minorities culture from the state, which significantly limits their ability of self-promotion, and the domination of the mass culture, the traditional cultural values of the Lemko minority are most fostered by the old generation, while the young people are more likely to succumb to commercial values [40]. However, the Lemko community still has strong inter-generational transfer of traditional forms of physical activity, hence one needs not fear for the survival of their national physical culture. It is the physical culture of this ethnic community, which to a large extent determines the scope and nature of its 
coexistence with the Polish majority and other minorities in the Polish society.

Our research of the broadly defined physical culture, located in the holistically perceived Lemko culture system, as well as the analysis of historical sources, clearly indicate that the Lemkos today still constitute an ethnic group, not just ethnographic group [38, 41, 42]. The factor determining Lemkos eligibility to be classified as an ethnic group is the still significant degree of cultural distinctness from the Polish society as a whole, as well as a high degree of sense of separateness from the rest of the society.

\section{Literature}

1. Huizinga J. (2007). Homo ludens. Games as a source of culture. Warszawa: Czytelnik. [in Polish]

2. Combs J.E. (2011). The world of games. The birth of a new ludic age. Warszawa: Wydawnictwo Uniwersytetu Warszawskiego. [in Polish]

3. Sułkowski B. (1985). The game. A sociological study. Warszawa: Wydawnictwo PWN. [in Polish]

4. Simonides D. (Ed.) (1977). Issues of folklore sociology. Opole: Wydawnictwo WSP. [in Polish]

5. Główny Urząd Statystyczny (2012). Results of the National Census of Population and Housing 2011. Basic information about demographic and social situation of the Polish population and housing. Warszawa: GUS. [in Polish]

6. Szumielewicz M. (2003). Manifestations of the Lemko culture in the South-East Poland. MA Thesis, WSS-G, Tyczyn. [in Polish]

7. Lipoński W. (2004). Rochwist and palant. An ethnological study of the former polish sports and physical games as compared to the european tradition. Poznań: AWF. [in Polish]

8. Misiak M. (2006). The Lemkos. Research of ethnic minorities in Europe. Wrocław: Wydawnictwo Uniwersytetu Wrocławskiego. [in Polish]

9. Kolberg O. (1865). The People. Their habits, their way of life, language, administration, proverbs, rituals, witchcraft, games, songs, music and dances. Warszawa: Drukarnia Jana Jaworskiego. [in Polish]

10. Burszta W.J. (1998). Cultural anthropology. Themes, theories, interpretations. Poznań: Zysk i s-ka. [in Polish]

11. Cieśliński R. (2010). Selected methods and techniques of field research in the field of sport and recreation ethnology. In I. Cieśliński, R. Cieśliński, I. Chaliburda (Eds.), Traditional forms of physical activity of the population of the eastern borderland of Poland. Biała Podlaska: AWF. [in Polish]

12. Callier E. (1880). Geographical dictionary of the Polish Kingdom. Warszawa: Ateneum. [in Polish]

13. Nowak J. (2000). A Lost World? They call them Lemkos. Kraków: Universitas. [in Polish]

14. Grzesik W., Traczyk T. (1997). From Komańcza to Bartne. Warszawa: PTTK. [in Polish]

15. Reinfuss R. (1949). Lemkos as an ethnographic group. Prace i Materiały Etnograficzne 7, 77-210. [in Polish]

16. Nalepa J. (1997/1998). Lemkos, Walachians and White Croats: comments on the origins of Ruthenia settlement in the Polish Prykarpattia. Acta Archaeologica Carpathica 34, 135-177. [in Polish]

17. Pieradzka K. (2009). On the routes of Lemkivshchyna. Krosno: Ruthenus. [in Polish]

18. Jurkowski M. (1962). The Lemkivshchyna. Slavia Orientalis 4, 240-254. [in Polish]

19. Czajkowski J. (1969). Historical and ethnical basis of the development of ethnographical groups in the southern part of the Rzeszowskie Voivodeship. Materiały Muzeum Budownictwa Ludowego w Sanoku 9, 5-40. [in Polish]
20. Kwilecki A. (1969). Historical and ethnic issues of the old Lemkivshchyna. Lud 53, 164-195. [in Polish]

21. Kwilecki A. (1964). Populations and distribution of national minorities in the Western. Parts of Poland. Przeglad $\mathrm{Za}$ chodni 4, 376-384. [in Polish]

22. Pudło K. (1992). The history (outline) of the Lemkos after World War II. The Lemkos in the history and culture of the Carpathians. Rzeszów: Muzeum Okręgowe. [in Polish]

23. Grela G. (1999). Circles of group identification - an analysis of the Lemko identity. Cultural anthropology. Lublin: Wydawnictwo UMCS. [in Polish]

24. Kwilecki A. (1966). Lemko sociological problems in the Western Parts of Poland. Kultura i Społeczeństwo 3, 87-104. [in Polish]

25. Kwilecki A. (1966). Issues Lemko settlement in Western Parts of Poland. Przeglad Zachodni 6, 292-314. [in Polish]

26. Żurko J. (1997). The Lemkos - between an ethnic group and a nation. National minorities in Poland. Wrocław: Wydawnictwo Uniwersytetu Wrocławskiego. [in Polish]

27. Ziółkowska M. (1989). Generous evening, generous day-rituals, customs and games. Warszawa: Ludowa Spółdzielnia Wydawnicza. [in Polish]

28. Graban M. (2006). Signs of death in the traditional beliefs of the Lemkos. Sprawy Wschodnie. Czasopismo Instytutu Wschodniego Uniwersytetu im. Adama Mickiewicza 3(13), 23-37. [in Polish]

29. Witkowski C. (1965). Annual Polish ceremonies and folk customs. Kraków: Muzeum Etnograficzne w Krakowie. [in Polish]

30. Chwalba A. (Ed.) (2005). Customs in Poland. From the Middle Ages to the modern times. Warszawa: Wydawnictwo PWN. [in Polish]

31. Ogrodowska B. (2001). Customs, rituals and traditions in Poland. Mały słownik. Warszawa: Verbinum. [in Polish]

32. R.A. (1998). Tradition - the strength of the Lemkos. Nowiny 193, 1. [in Polish]

33. Kwilecki A. (1970). Cohabitation with the Polish population and cultural changes amongst the Lemkos. Etnografia Polska 14, 1, 25-56. [in Polish]

34. Fischer S. (1967). Work migration of the Lemkos to the USA. Materiały Muzeum Budownictwa Ludowego w Sanoku 6, 7-19. [in Polish]

35. Augustyński W. (2001). Lemko the celebrations of Christmas. Almanach Sqdecki 4.

36. Janicka-Krzywda U. (1994). Russalia. Zahoroda 1, 7-8. [in Polish]

37. Piasecki E. (1922). Physical fun and games for children and youth - historical and ethnographic sources, mostly indigenous and oral tradition. Lwów: Księgarnia Polska. [in Polish]

38. Reinfuss R. (1990). Following the Lemkos. Warszawa: Wydawnictwo PWN. [in Polish]

39. Olszański T. (2003). Reflections on the Lemkivshchyna and the Lemkos. Almanach Karpacki 27. [in Polish]

40. Simonides D. (2010). Why have trees ceased to speak? Folk view of the world. Opole: Wydawnictwo Nowik. [in Polish]

41. Reinfuss R. (1946). The Cracow-highland borderland in the light of past and recent ethnographic research. Lud 36, 10. [in Polish]

42. Michna E. (1995). The Lemkos. An ethnic group or a nation? Kraków: Nomos. [in Polish]

Submitted: June 18, 2012

Accepted: November 27, 2012 